Ann. Génét. Sél. anim., I976, 8 (I), 4I-45.

\title{
OSMOTIC RESPONSE TESTS ON ERYTHROCYTES FOR THE DETECTION OF DOUBLE MUSCLE CARRIERS IN CATTLE ( ${ }^{1}$ )
}

\author{
W. A. KING, PARVATHI K. BASRUR, R. G. BROWN* \\ and $R$ T. BERG** \\ Dpt. of Biomedical Science, \\ O. V.C., University of Guelph, \\ * Dpt. of Animal and Poultry Science, \\ University of Guelph, \\ Ontario, Canada \\ ** Dpt. of Animal science, \\ University of Alberta, \\ Edmonton, Canada
}

\section{SUMMARY}

Erythrocyte harvested from heparinized whole blood of a group of cattle of various breeds including overtly double muscled animals and more or less normal carriers of the trait revealed an increased rate of hemolysis on exposure to osmotic shock as compared to normal Charolais cattle.

There is also a clearcut distinction between the rate of hemolysis of double muscled animals and normal carriers detected because they have some affinity with the double muscled and have transmitted the trait. They all seem in our samples to be heterozygotes in the generally admitted hypothesis that double muscling is due to a simple mendelian factor. It is hence suggested that the erythrocyte fragility test described in this report may be used for the identification of carriers which are often difficult to distinguish from normal animals on the basis of morphologic criteria.

Double muscling syndrome (hereditary muscular hypertrophy) characterized by massive muscles, reduced subcutaneous and intramuscular fat deposits, thin skin and light bones, has been reported to be a syndrome affecting beef cattle (see LAUVERGNe et al., I968 for review).

When fully expressed, the condition is easily recognized by the increased musculature, nota-

(') This note represents a part of the Master's Thesis submitted to the University of Guelph by W. A. King (I975: Hereditary Muscular Hypertrophy (Double Muscling) in Beef Cattle). 
bly in the hindquarters and by the characteristic crease in the muscle caused by the thin skin and reduced subcutaneous fat.

Although the carriers of this trait are desirable because of their relatively fast rate of growth during the first year and the quality of the carcasses, "double muscled "fetus often causes diffculty at parturition, and after birth, the affected animals tend to be extremely susceptible to stress. These problems, coupled with the retarded development of the reproductive organs in some of the double muscled animals present obstacles to a wider utilization of this trait in beef production.

This condition is recognised as a hereditary, mendelian, monofactorial trait but its expressivity is very variable and penetrance incomplete. Moreover, the degree of penetrance may vary according to the breed and in keeping with the emphasis of selection which could be for or against this trait (see Ménissier, I974, for review).

The presence of normal carriers which may sometimes be " normal overlaps " complicates the problem of selection and emphasises the need for a reliable method of genotype detection

Several attempts have been made in the past to characterize the genetic categories of double muscling, on the basis of histologic, histochemical and biochemical criteria. While some parameters tested, including the distribution and diameters of white muscle fibers, the creatinine levels in blood and urine and the integrity of collagen in double muscled animals, have shown marked difference from those of normal animals, these criteria were not absolutely unequivocal to be useful for the detection of normal overlap carriers of this traits (MENISSIER, 1974).

More recently, the histological and ultrastructural studies undertaken in our laboratory have shown that a generalized membrane defect may be the most consistent feature of this syndrome (KING and BASRUR, 1974).

Previous chemical analysis of muscle tissue from double muscled animals have shown that this condition is associated with an increase in the potassium/sodium ratios (LAWRIE et al., 1964). These observations seem to suggest that the primary defect may be at the cell membrane level in animals carrying the gene for double muscling. A generalized membrane defect will alter the integrity of the erythrocyte membranes and render them fragile (DACIE and LEwIS, I968). If such an alteration prevails, it can be detected by testing the osmotic response of erythrocytes from animals carrying double muscling gene and the test, if reliable, will be a great asset to the detection of normal carriers of this trait. This note concerns our preliminary studies to test this possibility.

Animals tested in this study included 33 cattle of various breeds stationed at the $U$ 'niversity of Alberta, Beef Breeding Station at Kinsella, Alberta. Fifteen of these animals were categorized as overtly affected (double muscled animals) and 7 as normal, based on their phenotypic features and breeding history. Eleven animals, grouped as normal carriers, were identified as such (by R.T.B.) on the basis of their varied degrees of phenotypic affinity to double muscling trait and on account of the fact that they have produced double muscled as well as apparently normal calves previously.

Ten milliliters of venus blood was drawn in heperanized syringes from animals belonging to these 3 categories and erythrocytes were harvested by spinning the blood at 5 ooo RPM in a clinical centrifuge and by aspirating off the plasma. The erythrocytes were then washed three times in isotonic saline with repeated centrifugation. One milliliter of the packed RBC was added to each of five centrifuge tubes containing $5 \mathrm{ml}$ each of $0,25 \mathrm{p}$. 100, $0,50 \mathrm{p}$. 100, $0,75 \mathrm{p}$. 100 and 0,9 p. 100 of sodium chloride solutions. The cells were suspended in these saline solution and let stand for five minutes following which the tubes were centrifuged for five minutes at 5000 RPM. The optical density (O. D.) of each supernatant solution was measured with a Beckman-DB-G grating spectrophotometer. The procedure was repeated varying the time for hemolysis (10, 20 , 30, 6o and 120 minutes after suspension in each solution) and percent hemolysis (O. D. in saline sample/O. D. in distilled water $\times 100)$ was plotted as a function of time.

The rate of hemolysis of all three categories increased with time and in relation to the decrease in the concentration of sodium chloride. At lower concentrations of sodium chloride $(0,5 \mathrm{p}$. Ico 
and $0,25 \mathrm{p}$. 100) the spectrophotometric measurements for all categories indicated roo p. I00 hemolysis within five minutes. At 0,75 p. Ioo and 0,9 p. Ioo concentrations, the difference between categories was very clear. These two concentrations have been choosen to illustrate the phenomenon in fig. I $(a$ and $b$ ).
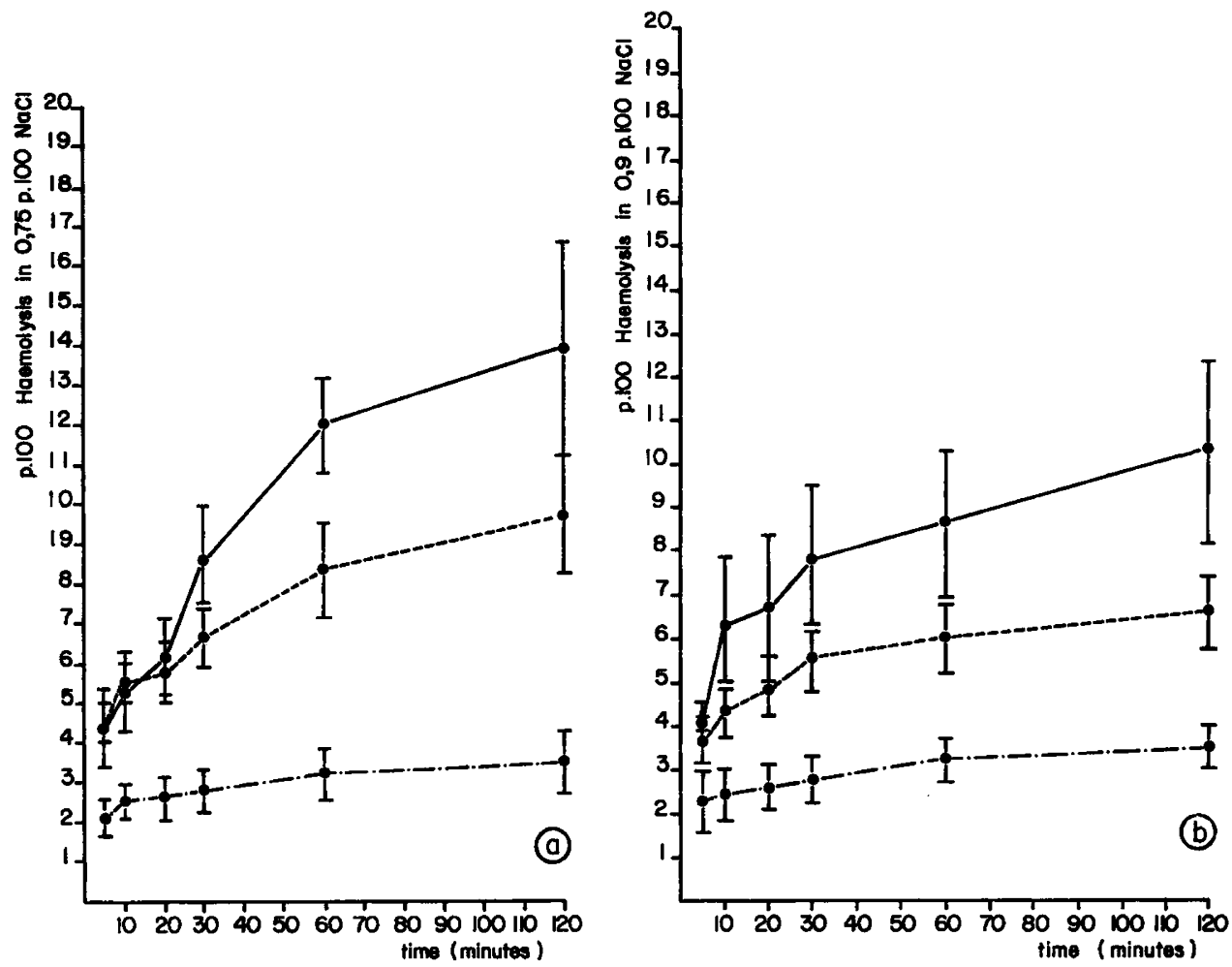

Fici. I. - (iraphs comparing perccnt haemolysis of erythrocytes from affected, carrier, and normal cattle in $\mathrm{NaCl}$ solutions at intervals from 5 to 120 minutes. The mean values of the samples and the mean $( \pm)$ standard error about these points are shown.
a) 0,75 p. $100 \mathrm{NaCl}$ solution
b) $0,90 \mathrm{p}$. $100 \mathrm{NaCl}$ solution

Comparaison des pourcentages d'érythrocytes hémolysés chez des bovins normaux, porteurs sains, ou présentant l'hypertrophie musculaire à des intervalles de temps de ij à 120 minutes : moyenne de chaque échantillon arec son erreur standard.

a) solution à 0,75 p. Ioo de $\mathrm{NaCl}$

b) solution à 0,90 p. roo de $\mathrm{NaCl}$

affected double muscling

....... normal carriers

- - - n normal animal

Both affected and normal carrier animals revealed a significant (at $\mathrm{P}=.05$ ) increase in the rate of hemolysis as compared to the control animals.

The results seem to indicate that $\mathrm{RBC}$ sensitivity to osmotic shock is a consistent feature of overtly affected (double muscled) animals and normal carriers. This would mean that there is a definite association between the erytrocytic osmotic response and the presence of the gene for double muscling.

There is no overlap between the data from affected animals and normal carriers after 30 mi- 
nutes (fig. I). This could mean that either the normal carriers included in this study are of a genetic make up (heterozygote) different from that of the affected animals (possibly homozygotes) or that the various factors influencing the general expressivity of the gene affect also the expressivity of the erythrocytes' response to osmotic shock.

On the basis of what is already known of the behaviour of the double muscling gene in beef breeds (see HANSET 1967 and LogEAY and VISSAC, 1970), the first explanation seems more acceptable. In the breeds quoted by these authors as well as in other, this trait tends to be fully recessive with a high penetrance in homozygotes and a low penetrance in heterozygotes. This would nearly exclude the presence of heterozygotes among affected animals as well as the homozygous normal overlaps among the normal carriers.

We had noted previously that the carriers and affected animals share certain ultrastructural abnormalities on the basis of which they may be distinguished from normal animals (KING and BASRUR, 1974), although the changes in fully affected animals were more severe than those seen in the normal carriers. The erythrocyte fragility test described here may prove to be a more pratical and reliable method than the electron microscopic method and some of the other methods previously used (MENissier, 1974). With the method discribed in this report the detection of carriers can be accomplished without subjecting the animals to the trauma of taking muscle biopsies. Moreover, the laboratory procedures are very simple, and, even more important, the test seems to be able to distinguish heterozygotes from homozygotes of the double muscling gene.

Reçu pour publication en mars 1976.

\section{ACKNOWLEDGMENTS}

This investigation was supported by the National Research Council of Canada and the Ontariv Ministry of Agriculture and Food. A travel award through the Franco-Canadian Cultural and Scientific Exchange Programme to the senior investigator (P. K. B.) which facilitated consultation with investigators in this area in France (Dr B. VISSAC and associates Dpt of Animal Genetics I.N.R.A., C.N.R.Z., Jouy en Josas) is gratefully acknowledged.

We would like extend our special thanks to Dr J.-J. Lauvergne of Dr Vissac's team for careful reading of the manuscript and for his suggestions in presenting this note.

\section{RÉSUMÉ}

\section{DÉTECTION DES BOVINS PORTEURS DU FACTEUR POUR LE CULARD PAR UN TEST D'HÉMOLYSE DES ÉRYTHROCYTES}

Les érythrocytes provenant d'échantillon de sang héparinisés d'un groupe de bovins de diverses races comprenant à la fois des culards et des porteurs sains du caractère ont montré une augmentation de leur taux d'hémolyse lors d'un choc osmotique par rapport aux érythrocytes d'animaux témoins normaux. On distingue également fort bien le taux d'hémolyse des culards de celui des porteurs sains ainsi classés car ils avaient quelques traits les rapprochant des culards et qu'ils avaient eu des culards dans leur descendance. Dans l'échantillon choisi tous les porteurs sains pouvaient être considérés comme des hétérozygotes dans l'hypothèse d'un déterminisme héréditaire mendélien monofactoriel généralement admise. Le test de fragilité des érythrocytes ainsi décrit pourrait être utilisé pour déceler certains porteurs difficiles à distinguer des animaux normaux sur la base d'un simple examen morphologique. 


\section{REFERENCES}

Dacie J. V., LewiS S. M., I968. Practical Haematology, 4 th ed. Churchill, London, p. I66.

HANSET R., 1967. Le problème de l'hypertrophie musculaire ou caractère culard dans la race bovine de Moyenne et Haute Belgique. Ann. Méd. Vét., 111, 140-180.

KING W. A., BASRUR P. K., 1974. Ultrastructural feature of hereditary muscular hypertrophy in cattle. Can. J. Genet. Cytol., 16, 707.

Lauvergne J. J., Boyazoglu J. G., Denise Hubert i968. Le phénomène culard chez les Bovins : bibliographie annotée. Bull. Tech. Dép. Génét. animale (Inst. Nat. Rech. Agr. Fr.), no 2, pp. 49.

Lawrie R. A., Pomeroy R. W., Wili.iams D. R., 1964. Studies in the muscles of meat animals IV. Comparative composition of muscles from "doppellender" and normal sibling heifers. J. Agr. Sci., 62, 89-92.

Logeay B., Vissic B., I970. Étude du caractère culard. V. Expérience de croisement entre bovins, culards et normaux. Ann. Génét. Sél. anim., 2, 5-17.

MÉnissier F., I974. Hypertrophie musculaire d'origine génétique chez les bovins : description, transmission, emploi pour l'amélioration de la production de viande. I er Congr. Génét. appl. Elev., Madrid 1, 85-107. 